\title{
Effects of exposure of the leaf abaxial surface to direct solar radiation on the leaf anatomical traits and photosynthesis of soybean (Glycine max L.) in dryland farming systems
}

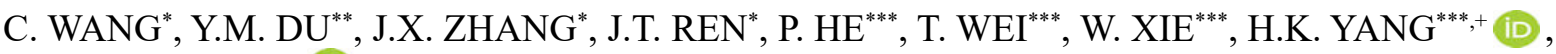 \\ and J.X. ZHANG ${ }^{*+}$ \\ College of Agriculture, Xinjiang Agricultural University, Urumqi, 830052 Xinjiang, China* \\ Yili Institute of Agricultural Science, Yining, 835000 Xinjiang, China ${ }^{* *}$ \\ Key Laboratory of Crop Eco-Physiology \& Farming System in Southwest China, Sichuan Agriculture University, \\ 611130 Chengdu, Sichuan Province, China***
}

\begin{abstract}
The frequent occurrence of monsoon winds usually leads to the formation of inverted soybean leaves. However, the effect of leaf inversion on photosynthetic capacity remains unclear. The responses of leaf anatomical traits, chlorophyll fluorescence induction kinetics parameters, photosynthetic capacity, and nonstructural carbohydrates of fully expanded leaves to inversion of leaves in two soybean cultivars were studied. Leaf inversion decreased the stomatal size and thickness of developed leaves. The net photosynthetic rate was significantly reduced under leaf inversion, which resulted from reduced excitation energy trapping and electron transport of PSII reaction center. Leaf inversion increased leaf temperature $10 \mathrm{~d}$ after leaf inversion but reduced the instantaneous water-use efficiency compared to normally oriented leaves. Due to the decreased light-saturated net photosynthetic rate, the soluble sugars of light-sensitive cultivar decreased significantly. In summary, leaf inversion deactivated the PSII reaction centers, reduced photosynthesis and nonstructural carbohydrates in upper canopy soybean leaves.
\end{abstract}

Keywords: carbohydrates; foliar anatomy traits; Glycine $\max (\mathrm{L}$.); light-response curves; photosynthesis.

\section{Introduction}

Soybean is a versatile crop grown worldwide. Soybean meal is the leading protein and energy source for human food and animal feed (Cai et al. 2020). Soybean is commonly grown in arid farming systems, accounting for $44 \%$ of China's total yield (Couée et al. 2006, Isoda et al. 2006). The frequent occurrence of monsoon winds

\section{Highlights}

- Leaf inversion leads to smaller stomata and thinner leaves

- Light-insensitive cultivar maintains $\mathrm{T}_{\text {leaf }}$ and $P_{\mathrm{N}}$ under leaf inversion

- Leaf inversion induced changes in the Chl $a$ fluorescence kinetics OJIP curves
Received 4 September 2020

Accepted 7 July 2021

Published online 12 August 2021

${ }^{+}$Corresponding authors

e-mail: zjxin401@126.com (J.X.Zhang) yhk159357@163.com (H.K. Yang)

Abbreviations: ABS/RC - absorption flux per reaction center at $\mathrm{t}=0$; AQY - apparent quantum yield; Chl - chlorophyll; $C_{\mathrm{i}}-$ intercellular $\mathrm{CO}_{2}$ concentration; $E$ - transpiration rate; $\mathrm{ET}_{0} / \mathrm{CS}$ - electron transport flux per cross-section at $\mathrm{t}=0 ; \mathrm{ET}_{0} / \mathrm{RC}$ - electron transport flux per reaction center at $\mathrm{t}=0 ; \mathrm{F}_{\mathrm{v}} / \mathrm{F}_{\mathrm{m}}$ - maximum quantum yield of PSII; $g_{\mathrm{s}}$ - stomatal conductance; LCP - light-compensation point; LSP - light-saturation point; $\mathrm{PI}_{\text {abs }}$ - performance index on absorption basis; $\mathrm{PI}_{\text {total }}$ - efficiency of energy conservation from absorbed photons to reduction of PSI end acceptors; $P_{\mathrm{N}}-$ net photosynthetic rate; $P_{\mathrm{Nmax}}-$ light-saturated net photosynthetic rate; RC/CS - relative number of active PSII reaction centers per excited cross-section; $R_{\mathrm{D}}$ - dark respiration rate; $\mathrm{T}_{\text {leaf }}-$ leaf temperature; TR $/ \mathrm{CS}-$ trapped energy flux per cross-section at $\mathrm{t}=0 ; \mathrm{TR}_{0} / \mathrm{RC}$ - trapped energy flux per reaction center at $\mathrm{t}=0$; WUE - water-use efficiency.

Acknowledgments: This work was supported by the National Natural Science Funds of China (grant number 31660367) and the Sichuan Science and Technology Program (grant number 2021YJ0504). We thank the reviewers and editor's help in revising this manuscript, their comments impressed me with the depth of knowledge and rigorous scientific attitude.

Conflict of interest: The authors declare that they have no conflict of interest. 
usually leads to the inversion of soybean leaves, exposing the abaxial leaf surface to direct solar radiation, resulting in a decrease in plant photosynthesis (Zhang et al. 2016, Paradiso et al. 2020). Therefore, investigating the effect of leaf inversion on foliar anatomy traits and photosynthetic capacity will provide a theoretical basis for exploring a possible methodology for alleviating the decrease in plant photosynthesis caused by monsoon winds.

In soybean, solar radiation commonly strikes the adaxial leaf surface, and most of the chloroplasts are concentrated in the palisade tissue. The diffuse solar radiation, which reaches the leaf's abaxial surface, can enhance primary plant productivity, but it is less efficient under diffuse than direct light (Martin et al. 2009, Ichiro et al. 2016, Earles et al. 2017, Richardson et al. 2017, Paradiso et al. 2020). The leaf's abaxial surface usually receives $10 \%$ of the light intensity and the leaf inversion exposes the abaxial leaf surface to more potent solar radiation energy and broader spectra (Paradiso and Marcelis 2012, Paradiso et al. 2020). The abaxial and adaxial surfaces of leaves respond to highenergy direct solar radiation and lower-energy diffuse solar radiation varies in the light environment because of leaf anatomical traits (Paradiso and Marcelis 2012, Nazar et al. 2015, Pan and Guo 2016, Paradiso et al. 2020). The responses of photosynthesis and stomatal behaviors to the light intensity of the abaxial and adaxial sides have been reported in various plants (Soares-Cordeiro et al. 2011, Wang et al. 2011, Paradiso et al. 2020). Effect of simulated leaf inversion on foliar anatomical traits, photosynthesis, and nonstructural carbohydrates in soybean leaves remains unclear.

It is generally accepted that solar radiation is the most critical environmental factor affecting foliar anatomical traits and photosynthesis of leaves (Wu et al. 2017, Matthews et al. 2018, Yang et al. 2018). The most crucial stage for the accumulation of soybean storage components is the seed-filling stage (Chen et al. 2020) and the interaction between leaves and the light environment is fundamental for the energy balance of soybean plants (Tamagno et al. 2020). Leaf photosynthesis depends on gas exchange, $\mathrm{CO}_{2}$ diffusion (Ellsworth et al. 2018), and carbon fixation (Ruiz-Vera et al. 2013). Leaf stomatal characteristics and the thickness of palisade tissue and sponge tissue constrained the evaporation, gas exchange, and $\mathrm{CO}_{2}$ assimilation rate (Sefton et al. 2002, Terashima et al. 2011, Chen et al. 2015, Verboven et al. 2015, Flexas et al. 2018, Xiong et al. 2018, Lawson and VialetChabrand 2019). The thicknesses of palisade and spongy tissues are strongly affected by light intensity (Bahamonde et al. 2018) and nitrogen and phosphorus contents (Li et al. 2017). Previous results have shown that thicker palisade tissues have higher photosynthetic efficiency (Chen et al. 2015). However, other studies have suggested that thicker leaves do not always accompany high photosynthetic capacity, owing to the efficiency of $\mathrm{CO}_{2}$ diffusion from the air to the chloroplast (Earles et al. 2018, Flexas et al. 2018, Ellsworth et al. 2018) and adaptive strategies when plants are subjected to abiotic stress (Wu et al. 2017, Feng et al. 2019). Stomata are mainly distributed on the abaxial surface and effective control of stomatal opening and closure significantly impacts leaf gas exchange, water balance, leaf temperature, and photosynthesis (Düring 2003, Voelker et al. 2016).

The abaxial surface of leaves is more susceptible to energetic solar radiation than the leaf adaxial surface because the stomata are mainly distributed on the abaxial surface (Li et al. 2010, Wang et al. 2020). When the abaxial surface of leaves is exposed to energetic solar radiation, the plant reduces the stomatal size and gas exchange actively to reduce leaf water loss. The light sensitivity of the abaxial surface of leaves cannot be entirely changed by an inversion treatment (Wang et al. 2011, Zhang et al. 2016). Solar radiation that reaches the leaf's abaxial surface causes irreversible reductions in plant photosynthesis and accumulation of seed-filling carbohydrates (Li et al. 2010). Previous studies have reported that leaf inversion reduces the effective regulation of stomatal opening and closure (Aasamaa and Aphalo 2017, Lawson and VialetChabrand 2019), and thus affects the intercellular $\mathrm{CO}_{2}$ concentration $\left(C_{\mathrm{i}}\right)$, leaf water loss, photosynthetic carbon fixation capacity, and the accumulation of plant biomass (Kromdijk et al. 2016). Notably, short-term leaf inversion reduces the net photosynthetic rate $\left(P_{\mathrm{N}}\right)$ by 20 to $30 \%$ (Turner and Singh 1984). In addition to these results, an exploration of how leaf inversion affects soybean photosynthesis is crucial for improving leaf photosynthesis in dryland farming systems.

The leaf's abaxial surface, which is exposed to direct solar radiation, naturally occurs as leaves sway because of monsoon winds. The application of leaf inversion to simulate the frequent occurrences of the effects of monsoon wind on leaf anatomical traits and photosynthesis capacity can provide a theoretical basis for exploring a possible methodology for alleviating the decrease in plant photosynthesis caused by monsoon winds. The present study aimed to investigate the responses of foliar anatomical traits, photosynthetic capacity, Chl fluorescence induction kinetics parameters, and nonstructural carbohydrates of fully expanded main stem leaves to light intensity and leaf inversion in two soybean cultivars with sensitivity to light intensity. We hypothesized that the frequent occurrence of monsoon winds leads to the inversion of soybean leaves at the grain-filling stage, which would reduce the gas exchange from the atmosphere to the primary sites of carbon fixation in the chloroplasts of soybean leaves.

\section{Materials and methods}

Experimental site: During the 2018 and 2019 cropping seasons, a field experiment was conducted at the experimental station $\left(43^{\circ} 50^{\prime} \mathrm{N}, 80^{\circ} 04^{\prime} \mathrm{E}\right)$ of the Yili Institute of Agricultural Science, a typical dryland region in China. The annual accumulative rainfall for 2018 and 2019 was 226.1 and $203.2 \mathrm{~mm}$, respectively. The experimental station's annual sun hours were $2,886.7 \mathrm{~h}$, and the average solar radiation at noon was $2,100 \mu \mathrm{mol}$ (photon) $\mathrm{m}^{-2} \mathrm{~s}^{-1}$ in 2019. The experimental site, located at midlatitude westerlies, and the soybean in this growing area 
frequently suffer from summer monsoon winds, leading to soybean leaf inversion, exposing the abaxial side of the leaf to the more energetic direct solar radiation [2,102 $\mu \mathrm{mol}$ (photon) $\mathrm{m}^{-2} \mathrm{~s}^{-1}$ at noon]. According to the Food and Agriculture Organization (FAO) soil taxonomy, the soil at the experimental site is a typical sandy loam. The root available soil $\mathrm{N}, \mathrm{P}$, and $\mathrm{K}$ contents were $54.8 \mathrm{~g} \mathrm{~kg}^{-1}$, $17.3 \mathrm{~g} \mathrm{~kg}^{-1}$, and $103.0 \mathrm{~g} \mathrm{~kg}^{-1}$, respectively. The total $\mathrm{N}$, $\mathrm{P}$, and $\mathrm{K}$ were $0.4 \mathrm{mg} \mathrm{kg}^{-1}, 1.1 \mathrm{mg} \mathrm{kg}^{-1}$, and $5.2 \mathrm{mg} \mathrm{kg}^{-1}$, respectively. Soil $\mathrm{N}, \mathrm{P}$, and $\mathrm{K}$ contents were measured using the Kjeldahl digestion method, Bray method, and flame emission spectrophotometry, respectively (Yang et al. 2020).

Experimental design: Two widely grown soybean cultivars, Xindadou27 (XD27) and Jiyu60 (JY60), were used as experimental materials. These two soybean cultivars had similar plant heights $(80-85 \mathrm{~cm})$ and growth periods (110-115 d). In a historical set of cultivars, the photosynthetic rate $\left(P_{\mathrm{N}}\right)$ of JY60 decreased more rapidly in the leaf inversion treatment than in XD27. Therefore, JY60 is a light-sensitive cultivar that was introduced by the Heilongjiang Academy of Agricultural Sciences of China $\left(45^{\circ} 58^{\prime} \mathrm{N}, 126^{\circ} 48^{\prime} \mathrm{E}\right)$. Xindadou 27 is a light-insensitive cultivar that was released from the Xinjiang Agricultural University of China $\left(43^{\circ} 57^{\prime} \mathrm{N}, 87^{\circ} 57^{\prime} \mathrm{E}\right)$. The split-plot experiment consisted of two treatment combinations with three replications each, two leaf inversion treatments as the main plot, and two light-sensitive cultivars as a subplot. Each plot was $4 \mathrm{~m}$ wide and $10 \mathrm{~m}$ long. For each treatment, 200 fully expanded leaves in the main stem were labeled with a tag at the seed-filling stage and fixed with a soft clip. These were labeled as the main plot, with the abaxial surface of the leaves exposed to direct solar radiation, while for the control group, regularly oriented fully expanded main stem leaves were used. Leaf inversion treatment was started from the soybean R5 stage to maturity. The labeled leaves were the fourth leaves from the top of the plant. The fourth leaf in the soybean plant received light intensity of 2,126 $\mu \mathrm{mol}$ (photon) $\mathrm{m}^{-2} \mathrm{~s}^{-1}$ of PPFD at noon. The leaf anatomical traits, photosynthetic capacity, and carbohydrate level responses to leaf inversion were determined. During the 2018 and 2019 cropping seasons, both XD27 and JY60 were sown on 11 April, with a density of 32.0 plants $\mathrm{m}^{-2}$. The row spacing was $40 \mathrm{~cm}$, and the plant spacing was $8 \mathrm{~cm}$. A drip irrigation system was applied to irrigate each plot and the total amount of irrigation was $3,000 \mathrm{~m}^{3} \mathrm{hm}^{-2}$. Nitrogen and phosphate were applied at the recommended rates of $144 \mathrm{~kg}(\mathrm{~N}) \mathrm{ha}^{-1}$ and $103 \mathrm{~kg}\left(\mathrm{P}_{2} \mathrm{O}_{5}\right) \mathrm{ha}^{-1}$, respectively, using urea $(46 \% \mathrm{~N})$ and diamine phosphate $(18 \% \mathrm{~N}$ and $46 \% \mathrm{P}_{2} \mathrm{O}_{5}$ ). A total of $28.1 \%$ of $\mathrm{N}$ and all of the $\mathrm{P}$ were applied at sowing. The remaining $\mathrm{N}$ was applied at $103.5 \mathrm{~kg}(\mathrm{~N}) \mathrm{ha}^{-1}$ by drip irrigation at the soybean R1 stage. Pest refers to local high-yielding practices.

Leaf anatomical structure: Leaf samples for both treatments were collected $10 \mathrm{~d}$ after the leaf inversion. The collected leaf samples were washed and fixed using a $50 \%$ formalin-acetic acid-alcohol (FAA) fixing liquid, consisting of $90 \%$ ethanol, $5 \%$ formaldehyde, and $5 \%$ glacial acetic acid, at $4^{\circ} \mathrm{C}$ for $1 \mathrm{~d}$. The collected leaf samples were dehydrated with a graded series of ethanol $(100,95,90,80,70,60$, and $50 \%)$ for $20 \mathrm{~min}$. The dehydrated samples were dried using a freeze dryer instead of tertial-butanol. Field emission scanning electron microscopy (FESEM) of model Zeiss SUPRA 55-VP (Konigsallee, Germany) was used to scan the leaf crosssections and abaxial surfaces of the collected leaf samples. The stomatal length, stomatal width, stomatal size, palisade tissue thickness, and spongy tissue thickness were quantified using ImageJ software (Rawak Software Inc., Stuttgart, Germany).

Photosynthetic traits: The adaxial surface of fully expanded leaves in the main stem for both treatments were illuminated when they were inside the CIRAS chamber in both treatments. The $P_{\mathrm{N}}$, transpiration rate $(E)$, stomatal conductance $\left(g_{\mathrm{s}}\right), C_{\mathrm{i}}$, and instantaneous water-use efficiency (WUE) were measured from both treatments at $0,2,5,10,15$, and $20 \mathrm{~d}$ after leaf inversion using a portable photosynthesis system (CIRAS-3, PP Systems, UK). Steady-state photosynthesis was achieved after the leaves were clamped for $5 \mathrm{~min}$, and the photosynthetic parameters were recorded at $1,800 \mu \mathrm{mol}$ (photon) $\mathrm{m}^{-2} \mathrm{~s}^{-1}$ light intensity, $400 \pm 5 \mu \mathrm{mol} \mathrm{mol}{ }^{-1} \mathrm{CO}_{2}$, and $70 \%$ humidity between 11:00-13:00 h (for details, see Wang et al. 2008). The instantaneous WUE was measured on the abaxial surface of leaves, and it was calculated using the following equation: WUE $=P_{\mathrm{N}} / E$, where $P_{\mathrm{N}}$ is the net photosynthetic value and $E$ represents the rate of leaf transpiration. The leaf temperature $\left(\mathrm{T}_{\text {leaf }}\right)$ was measured using an infrared thermometer (DT8380, Anymetre, China).

Photosynthetic light-response curves: Photosynthetic light-response curves of fully expanded leaves in the main stem of soybean were measured $10 \mathrm{~d}$ after leaf inversion using a portable photosynthesis system (CIRAS-3, PP Systems, London, UK) between 11:00-13:30 h at the soybean R5 expanding stage. The $P_{\mathrm{N}}$ was recorded at PPFDs of 2,$000 ; 1,800 ; 1,500 ; 1,200 ; 1,000 ; 800,600$, $400,200,150,100,50,30$, and $0 \mu \mathrm{mol}$ (photon) $\mathrm{m}^{-2} \mathrm{~s}^{-1}$, respectively. These measurements were recorded at a fixed $\mathrm{CO}_{2}$ concentration of $400 \pm 5 \mu \mathrm{mol} \mathrm{mol}^{-1}$ using $\mathrm{CO}_{2}$ cylinders. The photosynthetic light-response curves can be fitted with a nonlinear hyperbolic model (Farquhar et al. 2001), as follows:

$$
P_{\mathrm{N}}(I)=\frac{\alpha \mathrm{I}+P_{\mathrm{N} \max }-\sqrt{\left(\alpha \mathrm{I}+P_{\mathrm{N} \max }\right) \alpha \mathrm{I}+P_{\mathrm{N} \max }-4 \alpha \mathrm{I} P_{\mathrm{Nmax}}}}{2 \theta}-R_{\mathrm{D}}
$$

where $\alpha$ is the apparent quantum yield (AQY), I represents the photosynthetic photon flux density (PPFD), $P_{\text {Nmax }}$ is the maximum net photosynthetic rate, $R_{\mathrm{D}}$ is the dark respiration rate, and $\theta$ is the convexity. Linear regression analysis was performed using SPSS version 19.0 software (IBM, Chicago, Illinois, USA) in the PPFD of 0 to $2,000 \mu \mathrm{mol}$ (photon) $\mathrm{m}^{-2} \mathrm{~s}^{-1}$. The crossover point of this line with the $x$-axis (photosynthetically active radiation, PAR) was the light-compensation point [LCP, $\mu$ mol(photon) 
$\mathrm{m}^{-2} \mathrm{~s}^{-1}$, whereas the corresponding $x$-axis value for the crossover points along the $y$-axis was the light-saturation point [LSP, $\mu \mathrm{mol}$ (photon) $\mathrm{m}^{-2} \mathrm{~s}^{-1}$ ].

The diurnal variation of the $P_{\mathrm{N}}$ and $\mathrm{T}_{\text {leaf }}$ were determined on three fully expanded main-stem leaves for each plot using a CIRAS-3 Portable Photosynthesis System (CIRAS-3, PP Systems, UK) on bright days. The leaves were the fourth leaves from the top of the plant. Illumination was provided by sunlight, and the photosynthetic rate was recorded $15 \mathrm{~d}$ after treatment from 8:00-18:00 h, at 2-h intervals.

Fluorescence parameters: The rapid Chl $a$ fluorescence induction kinetics of fourth fully expanded leaves were measured $10 \mathrm{~d}$ after treatments using a plant efficiency analyzer (Pocket-PEA, Hansatech, Norfolk, UK) between 11:00-13:00 h. After leaf samples for each treatment were acclimatized to the dark for $30 \mathrm{~min}$ using a fixing leaf clip, the samples were illuminated with a saturating light pulse of 3,000 $\mu \mathrm{mol}$ (photon) $\mathrm{m}^{-2} \mathrm{~s}^{-1}$ for $2 \mathrm{~s}$, provided by an array of three light-emitting diodes $(650 \mathrm{~nm})$. The fast Chl $a$ fluorescence kinetics was recorded from $10 \mu \mathrm{s}$ to $1 \mathrm{~s}$, the fluorescence intensity at $20 \mu \mathrm{s}\left(\mathrm{F}_{\mathrm{O}}\right), 300 \mu \mathrm{s}\left(\mathrm{F}_{\mathrm{K}}\right)$, and $2 \mathrm{~ms}\left(\mathrm{~F}_{\mathrm{J}}\right)$ were collected, and all the collected data were analyzed using the program PEA Plus to obtain JIP-test parameters (Yusuf et al. 2010). These include $\mathrm{F}_{\mathrm{v}} / \mathrm{F}_{\mathrm{m}}$, maximum quantum yield of PSII; $\mathrm{RC} / \mathrm{CS}$, relative number of active PSII reaction centers per excited crosssection (CS); $\mathrm{TR}_{0} / \mathrm{CS}$, trapped energy flux per $\mathrm{CS}$ at $\mathrm{t}=0 ; \mathrm{ET}_{0} / \mathrm{CS}$, electron transport flux per $\mathrm{CS}$ at $\mathrm{t}=0$; $\mathrm{ABS} / \mathrm{RC}$, absorption flux per reaction center $(\mathrm{RC})$ at $\mathrm{t}=0 ; \mathrm{TR}_{0} / \mathrm{RC}$, trapped energy flux per $\mathrm{RC}$ at $\mathrm{t}=0 ; \mathrm{ET}_{0} / \mathrm{RC}$, electron transport flux per $\mathrm{RC}$ at $\mathrm{t}=0 ; \mathrm{PI}_{\mathrm{abs}}$, performance index on absorption basis; $\mathrm{PI}_{\text {total }}$, efficiency of energy conservation from absorbed photons to reduction of PSI end acceptors.

The Chl $a$ fluorescence rise kinetics (OJIP) parameters were normalized between $F_{O}$ and $F_{K}$ expressed as $V_{O K}$ $\left[\mathrm{V}_{\mathrm{OK}}=\left(\mathrm{F}_{\mathrm{t}}-\mathrm{F}_{\mathrm{O}}\right) /\left(\mathrm{F}_{\mathrm{K}}-\mathrm{F}_{\mathrm{O}}\right), 20-300 \mu \mathrm{s}\right]$, and between $\mathrm{F}_{\mathrm{O}}$ and $\mathrm{F}_{\mathrm{J}}$ expressed as $\mathrm{V}_{\mathrm{OJ}}\left[\mathrm{V}_{\mathrm{OJ}}=\left(\mathrm{F}_{\mathrm{t}}-\mathrm{F}_{\mathrm{O}}\right) /\left(\mathrm{F}_{\mathrm{J}}-\mathrm{F}_{\mathrm{O}}\right), 20 \mu \mathrm{s}\right.$ to $\left.2 \mathrm{~ms}\right]$; finally, the differences between the transients expressed as $\Delta \mathrm{V}_{\mathrm{OK}}\left[\Delta \mathrm{V}_{\mathrm{OK}}=\mathrm{V}_{\mathrm{OK}}\right.$ (treatment) $-\mathrm{V}_{\mathrm{OK}}$ (control) $]$ and $\Delta \mathrm{V}_{\mathrm{OJ}}\left[\Delta \mathrm{V}_{\mathrm{OJ}}=\mathrm{V}_{\mathrm{OJ}}\right.$ (treatment) $-\mathrm{V}_{\mathrm{OJ}}$ (control) $]$ were determined to visualize the so-called L-band and K-band (Dalberto et al. 2017).

Chlorophyll (Chl) content: The leaves for both treatments were collected and freeze-dried to measure the contents of leaf $\mathrm{Chl}$ and soluble carbohydrates. Leaf $\mathrm{Chl}$ was extracted with ethanol and assessed spectrophotometrically following the method of Lichtenthaler (1987). The Chl $a$, $\mathrm{Chl} b$, total $\mathrm{Chl}$, and total carotenoids were calculated using following formulas: Chl $a=13.95 \mathrm{OD}_{665}-6.88 \mathrm{OD}_{649}$, $\mathrm{Chl} b=24.96 \mathrm{OD}_{649}-7.32 \mathrm{OD}_{665}$, Car $=\left(1,000 \mathrm{OD}_{470}-\right.$ 2.05 Chl $a-114.8 \mathrm{Chl} b) / 245, \mathrm{Chl}=\mathrm{Chl} a+\mathrm{Chl} b$.

Nonstructural carbohydrates: The soluble sugars were extracted with $80 \%$ ethanol and quantified using the anthracene sulfuric acid method (Yang et al. 2017). In brief, $0.1 \mathrm{~g}$ of dried and powdered samples were extracted three times with $80 \%$ ethanol in a water bath at $80^{\circ} \mathrm{C}$.
Measurements were recorded in a 96-well polystyrene plate using a Benchmark microplate reader (Bio-Rad., Inc., California, USA) and quantified using glucose as a standard. The insoluble ethanol residue was used to extract the starch (Yang et al. 2017). The dried residue was kept in a boiling water bath for $15 \mathrm{~min}$, and then hydrolyzed with $9.2 \mathrm{M} \mathrm{HClO}_{4}$ for $15 \mathrm{~min}$ and extracted again using $2 \mathrm{~mL}$ of $4.6 \mathrm{M} \mathrm{HClO}_{4}$ for $10 \mathrm{~min}$. The supernatants were mixed, and the insoluble ethanol starch was measured spectrophotometrically at $620 \mathrm{~nm}$ using D-glucose as the standard.

Statistical analysis: All statistical data from the experiment were analyzed by two-way analysis of variance (ANOVA) using SPSS version 19.0 (SPSS Inc., Chicago, IL, USA). All data are presented as the mean \pm standard error, and the means were compared using least significant difference (LSD) tests, ${ }^{*} P<0.05,{ }^{* *} P<0.01$, in which the leaf inversion was set as the main plot, and the cultivars were set as the subplot. Graphs were plotted using SigmaPlot software version 12.5 (Systat Software, Inc., San Jose, California, USA). The contributions of each predictor variable to the decrease of $P_{\mathrm{N}}$ were analyzed by dominance analysis.

\section{Results}

Microstructure of soybean leaves: Microscopic observation of leaf cross-sections showed that leaf inversion significantly affected the palisade tissue of soybean leaves (Fig. 1, Table 1). The spongy mesophyll tissues of the leaf inversion treated plants were loosely attached, while the spongy mesophyll tissues of control plants were columnar, vertically oriented, and tightly packed. Microscopic

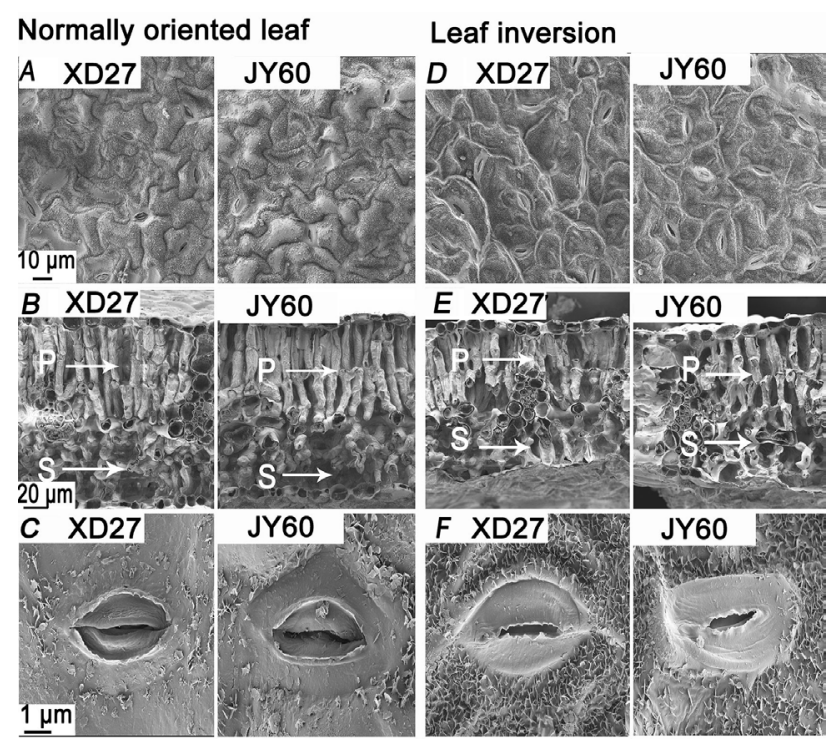

Fig. 1. The abaxial surface $(A, C, D, F)$ and cross-sections $(B, E)$ of the fourth main stem leaf for both leaf inversion and control plants for soybean cultivars XD27 and JY60: $(A-C)$ represent normally-oriented leaves; and $(D-F)$ represent the leaf inversion treatment. $\mathrm{P}$ - palisade tissue; $\mathrm{S}$ - spongy tissue. 
observation of the leaf's abaxial surface showed a withered and wrinkled abaxial surface. The stomatal size was significantly lower than that of the control plants in 2018 and 2019.

The ANOVA showed that the leaf anatomical traits were significantly affected by leaf inversion, but not by the cultivar and their interactions (Table 1). Average leaf inversion treatments in the two growing seasons, the stomatal length, stomatal width, stomatal size, and thickness of the palisade and spongy tissues of XD27 were
$13.3,48.5,42.7,19.3$, and $13.0 \%$ lower, respectively, than those of the control plants, and 16.9, 51.8, 31.9, 16.5, and $14.0 \%$ lower than those of the JY60 plants. However, there was no significant difference in stomatal density and the ratio of palisade and spongy tissue between the treatments for both cultivars.

Photosynthetic characteristics: Our results showed that the thicknesses of the palisade tissue and mesophyll cells were decreased by leaf inversion. Our experiments first

Table 1. Effects of leaf inversion on the leaf microstructure traits of soybean cultivars at $10 \mathrm{~d}$ after treatment. XD27 and JY60 represent soybean cultivars Xindadou27 and Jiyu60, respectively. PT/ST - the ratio of palisade tissue thickness to spongy tissue thickness. Data are expressed as means \pm SE $(n=6)$. Values with different letters in a single column indicate a significant difference at $P<0.05$. ** indicates significant difference at the 0.01 probability level, and NS means nonsignificant difference $(P>0.05)$.

\begin{tabular}{|c|c|c|c|c|c|c|c|c|}
\hline Cultivar & Treatments & $\begin{array}{l}\text { Stomatal } \\
\text { length }[\mu \mathrm{m}]\end{array}$ & $\begin{array}{l}\text { Stomatal } \\
\text { width }[\mu \mathrm{m}]\end{array}$ & $\begin{array}{l}\text { Stomatal } \\
\text { size }\left[\mu \mathrm{m}^{2}\right]\end{array}$ & $\begin{array}{l}\text { Stomatal } \\
\text { density }\left[\mathrm{mm}^{-2}\right]\end{array}$ & $\begin{array}{l}\text { Palisade tissue } \\
\text { thickness }[\mu \mathrm{m}]\end{array}$ & $\begin{array}{l}\text { Spongy tissue } \\
\text { thickness }[\mu \mathrm{m}]\end{array}$ & $\mathrm{PT} / \mathrm{ST}$ \\
\hline \multirow[t]{2}{*}{ XD27 } & CK & $12.70 \pm 0.28^{\mathrm{a}}$ & $4.93 \pm 0.16^{\mathrm{a}}$ & $43.65 \pm 2.05^{\mathrm{a}}$ & $243.50 \pm 14.09^{\mathrm{a}}$ & $114.28 \pm 3.02^{\mathrm{a}}$ & $83.37 \pm 2.85^{\mathrm{a}}$ & $1.40 \pm 0.66^{\mathrm{a}}$ \\
\hline & Leaf inversion & $11.01 \pm 0.47^{\mathrm{b}}$ & $2.54 \pm 0.29^{b}$ & $25.03 \pm 2.76^{\mathrm{b}}$ & $236.35 \pm 25.15^{\mathrm{a}}$ & $92.19 \pm 1.33^{b}$ & $72.50 \pm 2.76^{\mathrm{b}}$ & $1.30 \pm 0.54^{\mathrm{a}}$ \\
\hline \multirow[t]{2}{*}{ JY60 } & $\mathrm{CK}$ & $12.84 \pm 0.45^{\mathrm{a}}$ & $5.10 \pm 0.26^{\mathrm{a}}$ & $41.56 \pm 3.12^{\mathrm{a}}$ & $214.32 \pm 4.61^{\mathrm{a}}$ & $111.08 \pm 3.27^{\mathrm{a}}$ & $84.31 \pm 3.80^{\mathrm{a}}$ & $1.35 \pm 0.09^{\mathrm{a}}$ \\
\hline & Leaf inversion & $10.67 \pm 0.62^{\mathrm{b}}$ & $2.46 \pm 0.36^{\mathrm{b}}$ & $28.29 \pm 1.87^{\mathrm{b}}$ & $213.35 \pm 8.82^{\mathrm{a}}$ & $92.74 \pm 1.76^{b}$ & $72.51 \pm 3.94^{b}$ & $1.31 \pm 0.08^{\mathrm{a}}$ \\
\hline \multicolumn{9}{|c|}{ Source of variance } \\
\hline \multicolumn{2}{|c|}{ Leaf inversion (T) } & $* *$ & $* *$ & $* *$ & NS & $* *$ & $* *$ & NS \\
\hline \multicolumn{2}{|c|}{ Cultivars (C) } & NS & NS & NS & NS & NS & NS & NS \\
\hline \multicolumn{2}{|c|}{$\mathrm{T} \times \mathrm{C}$} & NS & NS & NS & NS & NS & NS & NS \\
\hline
\end{tabular}

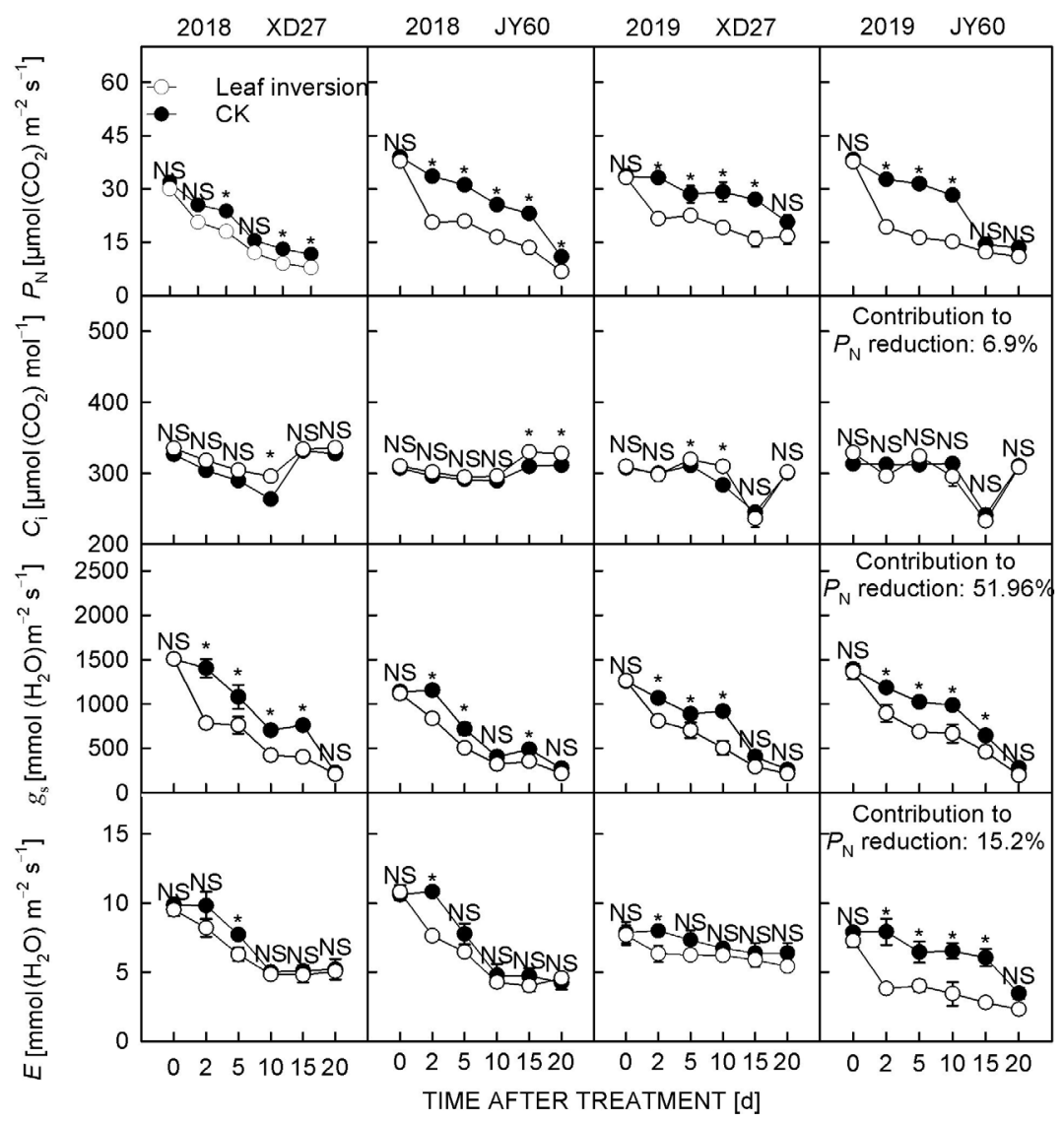

Fig. 2. Effect of leaf inversion on the photosynthetic characteristics of soybean cultivars XD27 and JY60 in the 2018 and 2019 cropping seasons. Data are expressed as means $\pm \mathrm{SE}(n=3)$. $P_{\mathrm{N}}-$ net photosynthetic rate; $C_{\mathrm{i}}$ - intercellular $\mathrm{CO}_{2}$ concentration; $g_{\mathrm{s}}$ - stomatal conductance; $E$ - transpiration rate. ${ }^{*}$ represents significant difference at the 0.05 probability level, and NS means nonsignificant difference $(P>0.05)$. 
measured the changes in the photosynthetic parameters of the two soybean cultivars (Fig. 2). The $P_{\mathrm{N}}$ of XD27 and JY60 was 22.3 and $29.3 \%$ lower in the leaf inversion treatments than that in the control plants. The $g_{\mathrm{s}}$ of the XD27 and JY60 plants were 24.6 and $21.2 \%$ lower, respectively, in the leaf inversion treatment than that in the control plants. However, there was no significant difference in the $C_{\mathrm{i}}$ and $E$, except for the $E$ observed in JY60. The dominance analysis showed that the decreased $g_{\mathrm{s}}$ explained $52.0 \%$ of the total variation in $P_{\mathrm{N}}$, followed by $E(15.2 \%)$, WUE $(13.3 \%), \mathrm{T}_{\text {leaf }}(12.7 \%)$, and $C_{\mathrm{i}}(6.9 \%)$.

Diurnal pattern of net photosynthetic rate: The diurnal variation of $P_{\mathrm{N}}$ was observed $15 \mathrm{~d}$ after leaf inversion to investigate the influence of daily light intensities on the $P_{\mathrm{N}}$ of leaves (Fig 3). Based on the leaf inversion treatments in the two growing seasons, the average $P_{\mathrm{N}}$ values of XD27 and JY60 were 37.2 and $29.9 \%$, respectively, which were lower in the leaf inversion treatments than that in the control plants. Notably, there was no significant difference between treatments at 8:00 h, and the maximum differences between treatments were observed from 10:00-14:00 h [2,095 $\mu \mathrm{mol}$ (photon) $\left.\mathrm{m}^{-2} \mathrm{~s}^{-1}\right]$ for both cultivars (Fig. 3).

Instantaneous water-use efficiency: The WUE was calculated to clarify the leaf inversion effect on the stomatal water exchange of soybean leaves (Fig. 3). The WUE of XD27 decreased after leaf inversion, whereas the WUE of JY60 increased $10 \mathrm{~d}$ after treatment, with peak values of JY60 higher than XD27. Based on the leaf inversion treatments in the two cultivars, the average WUE observed 10 and $15 \mathrm{~d}$ after leaf inversion was 26.3 and $28.9 \%$, respectively, which were lower than that in the control plants.

Leaf temperature: Given that leaf inversion leads to smaller stomatal dimensions and reduced WUE, our studies further investigated the daily $\mathrm{T}_{\text {leaf }}$ changes (Fig. 4). Averaging the leaf inversion treatments in the cropping seasons, the $\mathrm{T}_{\text {leaf }}$ of XD27 and JY60 in the leaf inversion treatments were 7.2 and $8.1 \%$ higher than that of the control group and there was no significant difference between the leaf inversion treatments at 0,2 , and $20 \mathrm{~d}$ after treatment. The daily variations in $\mathrm{T}_{\text {leaf }}$ showed significant differences between leaf inversion treatments at 10:00, 12:00, and 14:00 h. Averaged across years, the $\mathrm{T}_{\text {leaf }}$ of XD27 and JY60 were 4.8 and $6.8 \%$ higher than that of the control plants at 12:00 h.

The photosynthetic light-response curves were wellfitted by the rectangular hyperbolic model, as indicated by the coefficient of determination $\left(R^{2}\right)$ values higher than 0.997 for both cultivars (Table 2, Fig. 5). The ANOVA showed that the $P_{\mathrm{N} \max }, \mathrm{AQY}, R_{\mathrm{D}}$, LCP, and LSP were significantly affected by leaf inversion, but not by the cultivar and their interactions. The $P_{\text {Nmax }}$ of XD27 and JY60 decreased by 28.8 and $34.8 \%$, respectively, compared with that of the control plants. The values of AQY in XD27 and JY60 decreased by 16.3 and $23.5 \%$, respectively, compared with that of the control plants. The leaf inversion treatment decreased the LCP by an average of $18.1 \%$ for JY60 and
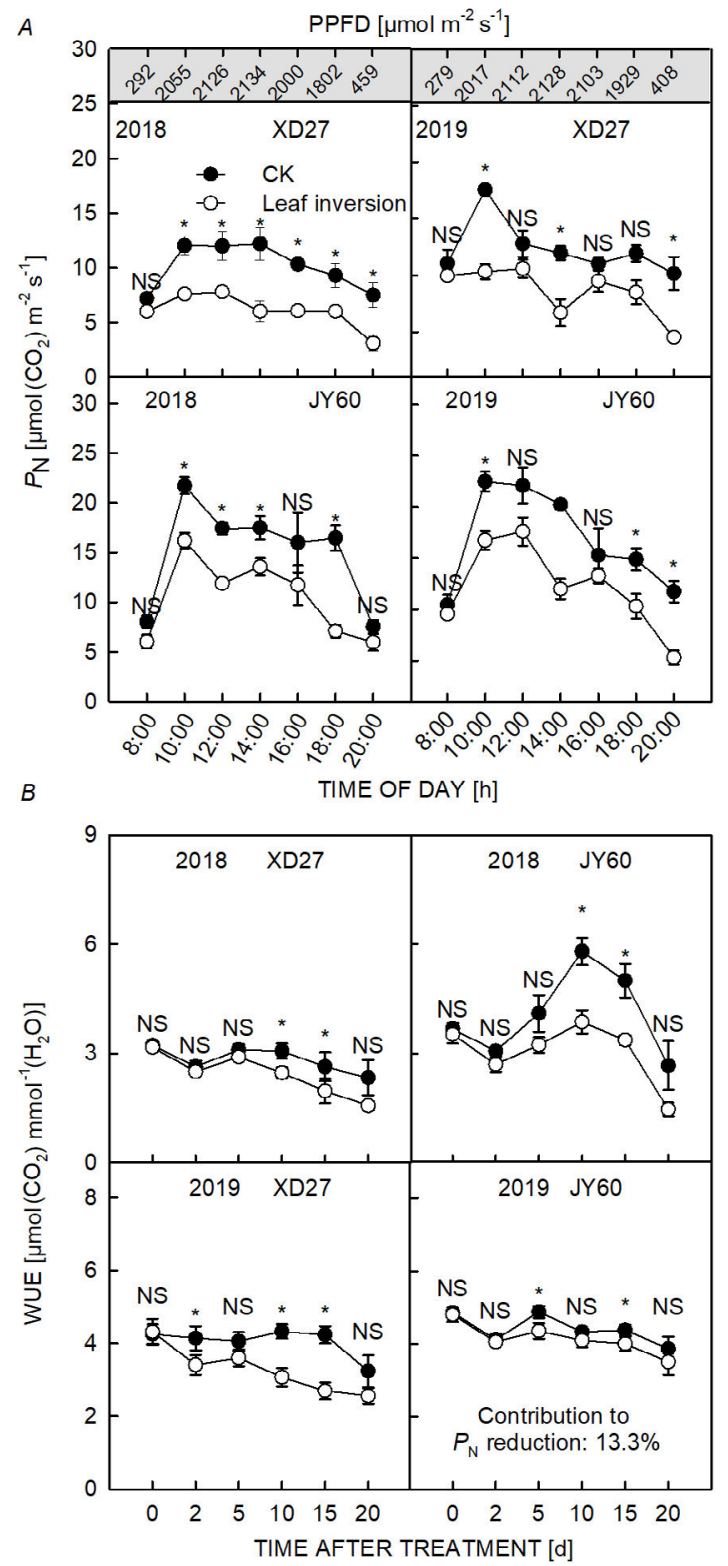

Fig. 3. Diurnal pattern of the net photosynthetic rate and instantaneous water-use efficiency (WUE) at $15 \mathrm{~d}$ after treatment in the 2018 and 2019 cropping seasons. XD27 and JY60 represent soybean cultivars, Xindadou27 and Jiyu60, respectively. Data are expressed as means $\pm \mathrm{SE}(n=3)$. * indicates significant difference at the 0.05 probability level, and NS means nonsignificant difference $(P>0.05)$.

there was no significant difference observed for the LCP of XD27. The leaf inversion treatment decreased the LSP and the range of light-compensation point to light-saturation point (LCP-LSP) by averages of 14.2 and $14.7 \%$.

Chl $\boldsymbol{a}$ fluorescence transient curves: Absorption per excited cross-section (ABS/CS), electron transport flux per reaction center $\left(\mathrm{ET}_{0} / \mathrm{RC}\right)$, and maximum quantum yield of PSII $\left(\mathrm{F}_{\mathrm{v}} / \mathrm{F}_{\mathrm{m}}\right)$ remained unchanged, but the electron 

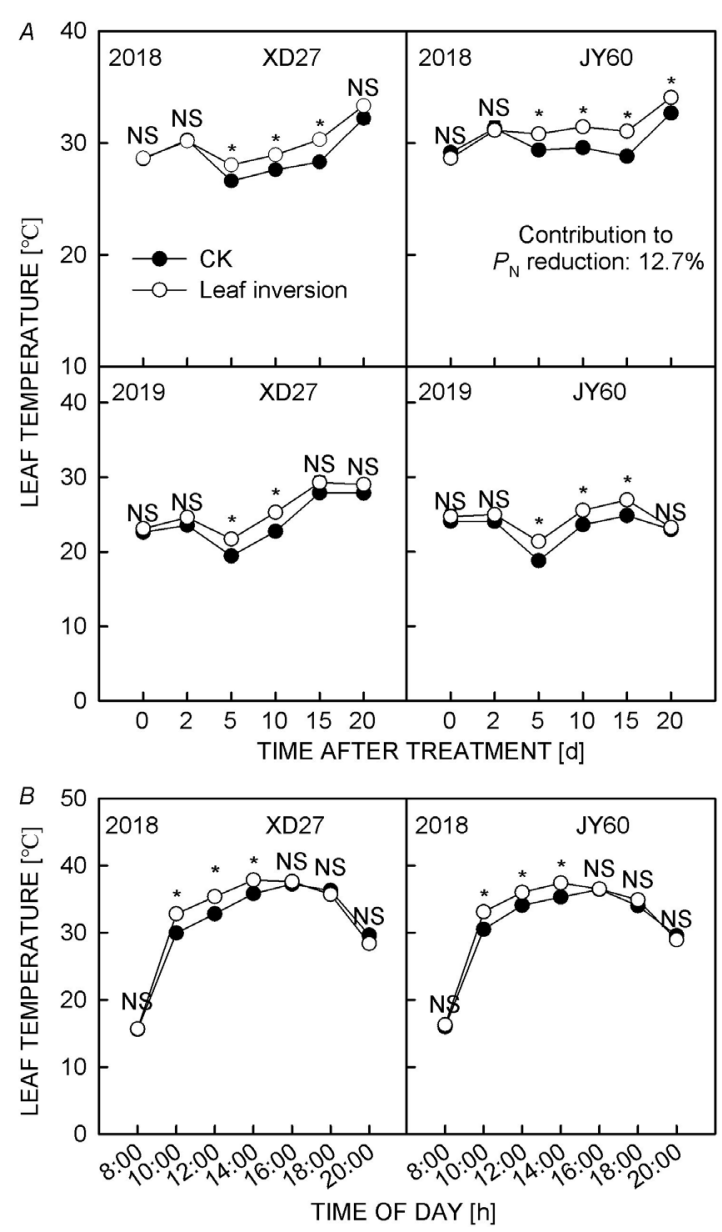

Fig. 4. Effect of leaf inversion on leaf temperature with days after treatment $(A)$ and time of day $(B)$ of XD27 and JY60. Data are expressed as means $\pm \mathrm{SE}(n=3)$. * indicates significant difference at the 0.05 probability level, and NS means nonsignificant difference $(P>0.05)$. transport per excited cross-section $\left(\mathrm{ET}_{0} / \mathrm{CS}\right)$ and active PSII reactions per excited cross-section (RC/CS) significantly decreased. For both cultivars, absorption flux (ABS/RC) and trapped energy flux per reaction center $\left(\mathrm{TR}_{0} / \mathrm{RC}\right)$ significantly increased. Leaf inversion decreased the $\mathrm{PI}_{\mathrm{abs}}$ and $\mathrm{PI}_{\text {total }}$ by 53.9 and $57.8 \%$, respectively. The differential inductance curves of the $\mathrm{O}-\mathrm{K}$ phase $\left(\Delta \mathrm{V}_{\mathrm{OK}}\right)$ and $\mathrm{O}-\mathrm{J}$ phase $\left(\Delta \mathrm{V}_{\mathrm{OJ}}\right)$ indicated changes $(0.076$ rel. units $)$ that occurred in $0.15 \mathrm{~ms}$, and the $\Delta \mathrm{V}_{\mathrm{OJ}}$ indicated that changes $(0.137 \mathrm{rel}$. units) occurred in $0.25 \mathrm{~ms}$. The path analysis indicated that RC/CS (0.643) played a critical role in $P_{\mathrm{N}}$ reduction under leaf inversion.

Nonstructural carbohydrates and leaf $\mathrm{Chl}$ content: In cultivar JY60, leaf inversion resulted in significantly lower contents of Chl $a, \mathrm{Chl} b$, total Chl, and carotenoid at 10, 15, and $20 \mathrm{~d}$ after leaf inversion, while there was no significant difference between the treatments in cultivar XD27 (Fig. 6). The average $\mathrm{Chl} a, \mathrm{Chl} b$, total $\mathrm{Chl}$, and carotenoid contents of JY60 were $19.3,19.1,19.3$, and $13.2 \%$ lower after the leaf inversion treatments than that in the control plants at 10,15 , and $20 \mathrm{~d}$ after treatment.

Leaf inversion reduced the soluble sugar and starch contents in the leaves of XD27 and JY60 at $20 \mathrm{~d}$ after leaf inversion (Fig. 6). In contrast, there were no significant differences between the treatments at $0 \mathrm{~d}$ after treatment. The average soluble sugars of XD27 and JY60 were 13.3 and $14.5 \%$, respectively, lower in the leaf inversion treatments than that in the control plants at $20 \mathrm{~d}$ after leaf inversion. The average starch content of XD27 and JY60 in the leaf inversion treatments was 16.2 and $12.2 \%$, respectively, lower than that of the control plants at $20 \mathrm{~d}$ after leaf inversion.

\section{Discussion}

Several studies have demonstrated that the contribution of the adaxial and abaxial surfaces of leaves to $P_{\mathrm{N}}$ varies with

Table 2. Photosynthetic light-response parameters of soybean leaves with leaf inversion and cultivars at $10 \mathrm{~d}$ after treatment. XD27 and JY60 represent soybean cultivars of Xindadou27 and Jiyu60. $P_{\mathrm{Nmax}}-$ maximum net photosynthetic rate; $R_{\mathrm{D}}-$ dark respiration rate; AQY - apparent quantum yield; LCP - light-compensation point; LSP - light-saturation point; LCP-LSP - the range of lightcompensation point to light-saturation point. Different letters indicate a statistically significant level at $P<0.05$. ${ }^{*}$ and $* *$ indicate significant difference at the 0.05 and 0.01 probability levels, respectively, and NS means nonsignificant difference $(P>0.05)$. Data are expressed as means $\pm \operatorname{SE}(n=6)$.

\begin{tabular}{|c|c|c|c|c|c|c|c|}
\hline Cultivar & Treatment & $\begin{array}{l}P_{\mathrm{Nmax}} \\
{\left[\mu \operatorname{mol}\left(\mathrm{CO}_{2}\right)\right.} \\
\left.\mathrm{m}^{-2} \mathrm{~s}^{-1}\right]\end{array}$ & $\begin{array}{l}R_{\mathrm{D}} \\
{\left[\mu \mathrm{mol}\left(\mathrm{CO}_{2}\right)\right.} \\
\left.\mathrm{m}^{-2} \mathrm{~s}^{-1}\right]\end{array}$ & $\begin{array}{l}\mathrm{AQY} \\
{\left[\mathrm{mol}^{-}\left(\mathrm{CO}_{2}\right)\right.} \\
\left.\mathrm{mol}^{-1}(\text { photon})\right]\end{array}$ & $\begin{array}{l}\mathrm{LCP} \\
{\left[\mu \mathrm{mol}\left(\mathrm{CO}_{2}\right)\right.} \\
\left.\mathrm{m}^{-2} \mathrm{~s}^{-1}\right]\end{array}$ & $\begin{array}{l}\text { LSP } \\
{\left[\mu \mathrm{mol}\left(\mathrm{CO}_{2}\right)\right.} \\
\left.\mathrm{m}^{-2} \mathrm{~s}^{-1}\right]\end{array}$ & $\begin{array}{l}\text { LCP-LSP } \\
{\left[\mu \mathrm{mol}\left(\mathrm{CO}_{2}\right)\right.} \\
\left.\mathrm{m}^{-2} \mathrm{~s}^{-1}\right]\end{array}$ \\
\hline XD27 & $\begin{array}{l}\text { CK } \\
\text { Leaf inversion }\end{array}$ & $\begin{array}{l}41.3 \pm 1.3^{\mathrm{a}} \\
29.4 \pm 0.4^{\mathrm{b}}\end{array}$ & $\begin{array}{l}3.2 \pm 0.3^{\mathrm{a}} \\
2.5 \pm 0.4^{\mathrm{ab}}\end{array}$ & $\begin{array}{l}0.049 \pm 0.001^{\mathrm{ab}} \\
0.041 \pm 0.003^{\mathrm{bc}}\end{array}$ & $\begin{array}{l}59.1 \pm 2.3^{\mathrm{a}} \\
56.5 \pm 1.8^{\mathrm{a}}\end{array}$ & $\begin{array}{l}909.9 \pm 43.2^{\mathrm{a}} \\
786.5 \pm 33.6^{\mathrm{bc}}\end{array}$ & $\begin{array}{l}850.8 \pm 47.5^{\mathrm{a}} \\
730.0 \pm 53.5^{\mathrm{bc}}\end{array}$ \\
\hline JY60 & $\begin{array}{l}\text { CK } \\
\text { Leaf inversion }\end{array}$ & $\begin{array}{l}41.4 \pm 1.3^{\mathrm{a}} \\
27.0 \pm 2.5^{\mathrm{b}}\end{array}$ & $\begin{array}{l}2.8 \pm 0.3^{\mathrm{a}} \\
1.7 \pm 0.1^{\mathrm{b}}\end{array}$ & $\begin{array}{l}0.051 \pm 0.002^{\mathrm{a}} \\
0.039 \pm 0.001^{\mathrm{c}}\end{array}$ & $\begin{array}{l}48.0 \pm 1.7^{\mathrm{b}} \\
39.3 \pm 2.3^{\mathrm{c}}\end{array}$ & $\begin{array}{l}860.8 \pm 16.1^{\mathrm{ab}} \\
732.3 \pm 15.2^{\mathrm{c}}\end{array}$ & $\begin{array}{l}812.9 \pm 16.4^{\mathrm{ab}} \\
693.0 \pm 71.0^{\mathrm{c}}\end{array}$ \\
\hline \multicolumn{8}{|c|}{ Source of variance } \\
\hline \multicolumn{2}{|c|}{ Treatment $(\mathrm{T})$} & $*$ & $*$ & $*$ & $*$ & $*$ & $* *$ \\
\hline \multicolumn{2}{|c|}{ Cultivar (C) } & NS & NS & NS & NS & NS & NS \\
\hline \multicolumn{2}{|c|}{$\mathrm{T} \times \mathrm{C}$} & NS & NS & NS & NS & NS & NS \\
\hline
\end{tabular}


A
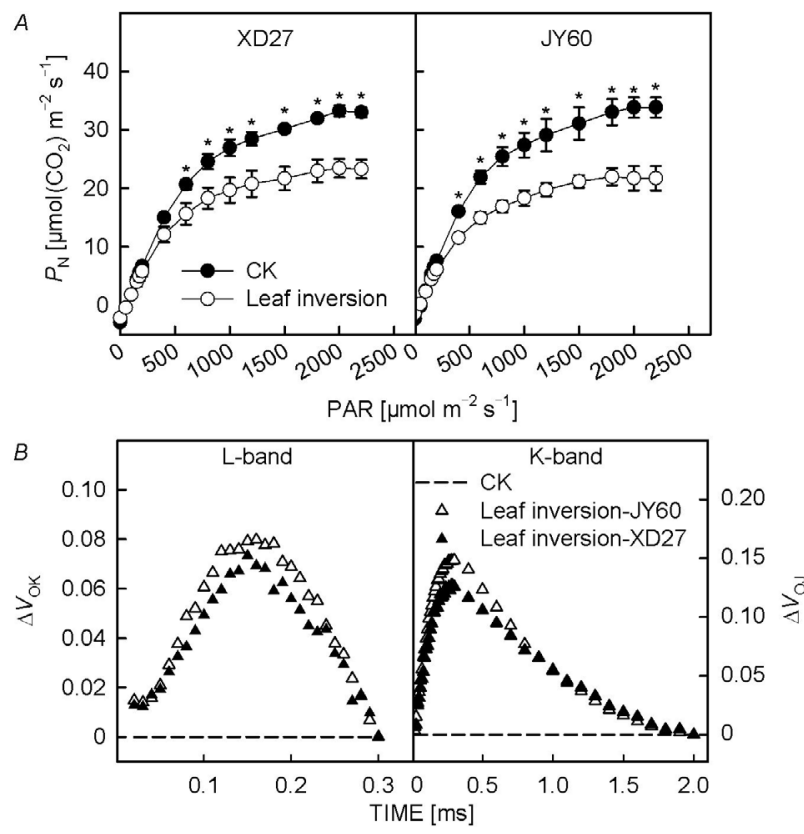

c

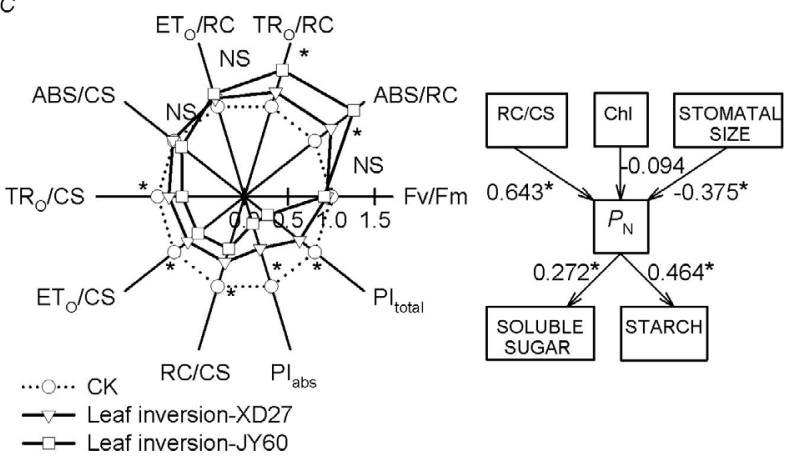

Fig. 5. Net photosynthetic rate $\left(P_{\mathrm{N}}\right)$-photosynthetically active radiation (PAR) response curves $(A), \mathrm{Chl} a$ fluorescence transient curves $(B)$, and fluorescence parameters $(C)$ for XD27 and JY60 under leaf inversion treatment in 2019. Chlorophyll $a$ fluorescence transient curves normalized between $F_{O}$ and $F_{K}$ expressed as $V_{O K}$ $\left[\mathrm{V}_{\mathrm{OK}}=\left(\mathrm{F}_{\mathrm{t}}-\mathrm{F}_{\mathrm{O}}\right) /\left(\mathrm{F}_{\mathrm{K}}-\mathrm{F}_{\mathrm{O}}\right)\right]$, between $\mathrm{F}_{\mathrm{O}}$ and $\mathrm{F}_{\mathrm{J}}$ expressed as $\mathrm{V}_{\mathrm{OJ}}$ $\left[\mathrm{V}_{\mathrm{OJ}}=\left(\mathrm{F}_{\mathrm{t}}-\mathrm{F}_{\mathrm{O}}\right) /\left(\mathrm{F}_{\mathrm{J}}-\mathrm{F}_{\mathrm{O}}\right) . \Delta \mathrm{V}_{\mathrm{OX}}=\mathrm{V}_{\mathrm{OX}}\right.$ (treatment) $-\mathrm{V}_{\mathrm{OX}}$ (control). XD27 and JY60 represent soybean cultivars Xindadou27 and Jiyu60, respectively. $F_{v} / F_{m}-$ maximum quantum yield of PSII; $\mathrm{RC} / \mathrm{CS}$ - relative number of active PSII reaction centers per excited cross-section $(\mathrm{CS}) ; \mathrm{TR}_{0} / \mathrm{CS}$ - trapped energy flux per $\mathrm{CS}$ at $\mathrm{t}=0 ; \mathrm{ET}_{0} / \mathrm{CS}-$ electron transport flux per $\mathrm{CS}$ at $\mathrm{t}=0$; $\mathrm{ABS} / \mathrm{RC}-$ absorption flux per reaction center $(\mathrm{RC})$ at $\mathrm{t}=0$; $\mathrm{TR}_{0} / \mathrm{RC}$ - trapped energy flux per $\mathrm{RC}$ at $\mathrm{t}=0 ; \mathrm{ET}_{0} / \mathrm{RC}-$ electron transport flux per $\mathrm{RC}$ at $\mathrm{t}=0 ; \mathrm{PI}_{\mathrm{abs}}-$ performance index on absorption basis; $\mathrm{PI}_{\text {total }}$ - efficiency of energy conservation from absorbed photons to reduction of PSI end acceptors. * indicates significant difference at the 0.05 probability level, NS - not significant. Bars mean standard error (SE; $n=3$ ).

growth conditions, genetic traits, and plant species (Martin et al. 2009, Soares-Cordeiro et al. 2011). Alternating adaxial, abaxial, and adaxial irradiation to simulate windinduced leaf swaying has demonstrated that the abaxial surface of leaves exposed to direct solar radiation decreased the $P_{\mathrm{N}}$ on both sides of the leaves (Zhang et al. 2016). In this study, leaf inversion significantly decreased $P_{\mathrm{N}}$ and $g_{\mathrm{s}}$ but not $C_{\mathrm{i}}$ and thus, one can conclude that stomatal closure is the primary reason for the reduced $g_{\mathrm{s}}$. The reduced $g_{\mathrm{s}}$ in turn downregulated $P_{\mathrm{N}}$ which agrees with Pandey et al. (2007). Our view that changes in leaf anatomy determine photosynthesis reduction appears to agree with a previous study (Martin et al. 2009). The spongy mesophyll tissues are located on the abaxial side of the leaves, which are the active sites for gas exchange. The palisade mesophyll tissues are located on the adaxial surface of the leaves, which is the active site for light absorption (Evans 1999, Li et al. 2007). In this study, leaf inversion reduced stomatal size, stomatal density, palisade tissue, and spongy tissue thickness, partly explaining the decreased $P_{\mathrm{N}}$ in leaf inversion treatments. Similar results were also observed in trees and herbs (Zhang et al. 2016), suggesting that alternating adaxial and abaxial surfaces suppressed $P_{\mathrm{N}}$. These results suggest that the leaf's abaxial surface is exposed more to direct solar radiation, which leads to thinner leaves, smaller stomata, and suppressed leaf photosynthesis. Thinner leaves have been reported to benefit $\mathrm{CO}_{2}$ fixation by reducing the effective $\mathrm{CO}_{2}$ path length (Terashima et al. 2006, Earles et al. 2018, 2019; Ellsworth et al. 2018), which is presumably not enough to compensate for the decreased leaf photosynthesis caused by leaf inversion. Further studies are required to determine the mesophyll conductance to $\mathrm{CO}_{2}$ in leaf inversion treatments.

The stomatal response is a critical physiological adaptive mechanism that affects $\mathrm{H}_{2} \mathrm{O}$ transport, heat transfer, and $\mathrm{CO}_{2}$ diffusion, affecting the photosynthetic capacity and WUE of leaves (Fanourakis et al. 2016, Earles et al. 2019, Lawson and Vialet-Chabrand 2019, Harrison et al. 2020). Stomatal regulation often occurs after $\mathrm{T}_{\text {leaf }}$ increases, leading to the inhibition of $\mathrm{CO}_{2}$ flux into the leaf when the abaxial surface is exposed to direct solar radiation. Stomatal responses to light intensity have been shown to vary depending on the genotype and environmental factors (Durand et al. 2020). Light intensity has a substantial stimulatory effect on cuticular permeability and stomatal closure because the stomata are mainly distributed on the abaxial surface of the leaf, and they are more sensitive to environmental changes (SoaresCordeiro et al. 2011, Fanourakis et al. 2019). In this study, leaf inversion significantly reduced the stomatal size on the abaxial surface of leaves, which might be attributed to an active adaptation strategy, enabling plants to adapt to intense direct solar radiation and reduce excessive transpiration of leaves. Similar results were also observed in a previous study (Das et al. 2015).

The stomatal factor was the main reason for the decrease in $P_{\mathrm{N}}$ at a recoverable stress level, while it was considered that the nonstomatal limitations were the main reason for the decrease in $P_{\mathrm{N}}$ at the unrecoverable stress level (Yu et al. 2015, Hao et al. 2019). It was reported that salt, heavy metal, and osmotic stress induce significant changes in Chl $a$ fluorescence rise kinetics, which elucidated significant alternations in PSII bioenergetics and many photosynthetic processes (Yusuf et al. 2010, Adamski et al. 

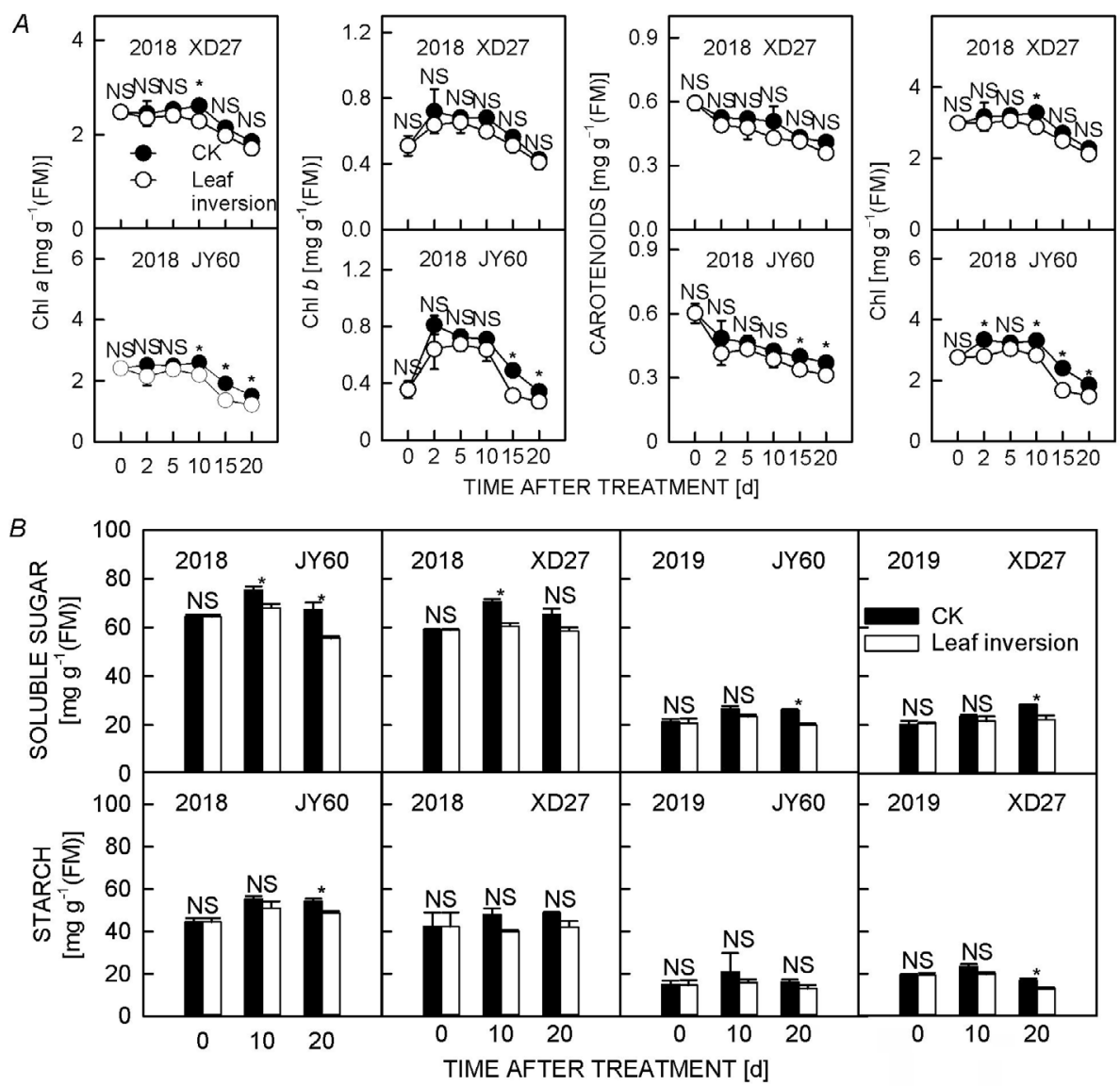

Fig. 6. Effects of leaf inversion on leaf chlorophyll, carotenoid, soluble sugar, and starch contents in leaves of XD27 and JY60. XD27 and JY60 represent soybean cultivars Xindadou27 and Jiyu60, respectively. Chl $a$ - chlorophyll $a$; Chl $b$ - chlorophyll $b$; Chl chlorophyll. * indicates significant difference at the 0.05 probability level, and NS means nonsignificant difference $(P>0.05)$. Bars mean standard error (SE; $n=3)$.

2011). In the present study, leaf inversion decreased $P I_{a b s}$ and $\mathrm{PI}_{\text {total }}$, and both normalized L- and K-bands always showed positive curves, which indicated that leaf inversion decreased energy connectivity among PSII units and dissociation of the oxygen-evolving complex (Adamski et al. 2011). Thus, leaf inversion-decreased $P_{\mathrm{N}}$ mainly attributed to nonstomatal limitation because leaf inversion reduced electron transport $\left(\mathrm{ET}_{0} / \mathrm{CS}\right)$ and excitation energy trapping $\left(\mathrm{TR}_{0} / \mathrm{CS}\right)$, whereas leaf inversion did not affect intercellular $\mathrm{CO}_{2}$ concentration $\left(C_{\mathrm{i}}\right)$. These findings suggest that the deactivation of PSII reaction center (RC/CS) might be the main reason for the $P_{\mathrm{N}}$ reduction under leaf inversion. Similar results have been reported for castor bean (Ricinus communis L.; Dalberto et al. 2017). The diurnal pattern of $P_{\mathrm{N}}$ showed a significantly lower peak value in the leaf inversion treatment, indicating that the abaxial surface of leaves, which were exposed to a more potent solar radiation energy and broader spectra, reduced the leaf photosynthetic capacity at noon (Fig. 5). Continuous leaf inversion led to an unrecoverable reduction in $P_{\mathrm{N}}$ at $10 \mathrm{~d}$ after leaf inversion, presumably due to decreased self-repair capability.

Leaf inversion led to an increase in the $\mathrm{T}_{\text {leaf }}$ by 7.2 and $8.1 \%$, respectively, for the cultivars XD27 and JY60, compared with those of control plants (Fig. 4). In Vicia faba plants, the net assimilation rate achieved an optimum value when the $\mathrm{T}_{\text {leaf }}$ was $26-27^{\circ} \mathrm{C}$ (Avola et al. 2008). In this study, the average PAR and air temperature were
2,044.2 $\mu \mathrm{mol}$ (photon) $\mathrm{m}^{-2} \mathrm{~s}^{-1}$ and $37^{\circ} \mathrm{C}$ between 10:00 18:00 $\mathrm{h}$ at $0 \mathrm{~d}$ after treatment in two years, respectively. Leaf inversion treatments reduced the $E$ of leaves, which was only observed for JY60 in 2019, partly explaining the increased $\mathrm{T}_{\text {leaf }}$. Notably, the increased $\mathrm{T}_{\text {leaf }}$ for the soybean cultivar JY60 was higher than that of XD27, and the decreased $E$ was only observed in JY60. These results suggest that the leaves of JY60 were more sensitive to direct solar radiation than that of XD27. This result might be because the abaxial surface of XD27 has a more robust capability of stomatal regulation to avoid excessive water loss by leaf transpiration. The leaf inversion treatment showed a significant photosynthetic break at 14:00 h, and the value of $P_{\mathrm{N}}$ was significantly lower than that of the control plants. We speculate that this might be attributed to the low light-saturation point of the abaxial side of the leaf, which agrees with the results in a study of rose plants (Paradiso and Marcelis 2012, Paradiso et al. 2020). These results suggest that leaf inversion increased the $T_{\text {leaf }}$ at 5 and $10 \mathrm{~d}$ after treatment, and the light-insensitive cultivar XD27 has a more robust capability to maintain $\mathrm{T}_{\text {leaf }}$ under the leaf inversion treatment.

The $P_{\mathrm{N}}-$ PAR response curves of soybean leaves were fitted accurately using the rectangular hyperbolic model (Herrmann et al. 2020), as indicated by the $R^{2}$. Leaf inversion limited plant photosynthesis by decreasing $P_{\text {Nmax }}$, AQY, and LSP and decreasing the LCP-LSP, which agrees with previous results (Proietti and Palliotti 
1997, Paradiso et al. 2020). The $P_{\mathrm{N} \max }$ was significantly lower in all leaf inversion treatments, suggesting that leaf inversion decreased the potential photosynthetic capacity of soybean leaves. The AQY is an estimated value of the maximum efficiency of light congestion during $\mathrm{CO}_{2}$ assimilation (Paradiso and Marcelis 2012). In this study, the AQY was significantly lower in the leaf inversion for the light-sensitive cultivar JY60 $(P<0.05)$, but not for the light-insensitive cultivar XD27 $(P>0.05)$, suggesting that leaf inversion decreased the utilization of solar radiation by soybean leaves. Additionally, the LSP and LCP-LSP of the inverted leaves were significantly reduced, suggesting that the potential of inverted leaves to use light energy was weakened. Dark respiration plays a pivotal role in carbon sequestration in environments that constrain variation in photosynthesis (Xu et al. 2013). In this study, the leaf inversion decreased $R_{\mathrm{D}}$ of light-sensitive cultivar JY60 but not light-insensitive cultivar XD27. The reduction of $R_{\mathrm{D}}$ was beneficial for the plant to maintain its metabolic balance by reducing the carbon loss of respiration under low solar radiation conditions. Similar adaptive strategies have also been observed under shading (Pires et al. 2011) and water stress (Xu et al. 2013). These results suggest that leaf inversion decreased the potential photosynthetic capacity of soybean leaves.

Numerous studies have reported that starch degradation in leaves is responsible for soluble sugar contents that protect plants against abiotic stress (Couée et al. 2006, Singh et al. 2015, Thalmann and Santelia 2017). In this study, both soluble sugar and starch contents decreased in the leaf inversion treatments at $20 \mathrm{~d}$ after leaf inversion for cultivar JY60, while there was no significant difference between the soluble sugar and starch content for treatments of the XD27 cultivar in 2018. These results can be attributed to the decreased $P_{\mathrm{N}}$ and the accumulation of starch in the leaves, which agrees with Iqbal et al. (2019). The decreased soluble sugar in our study might have resulted from the leaf inversion adaptation process. Sugars have been reported as signal molecules that protect cells from protein denaturation by protein-cell membrane hydrogen bonding during abiotic stress (Keunen et al. 2013). One possible reason is that the abaxial surface is usually adapted to the lower-energy diffuse solar radiation. The abaxial surface of leaves exposed to direct solar radiation caused by leaf inversion decreased the photosynthetic capacity of soybean leaves, which may be far greater than its self-repairing capability. Therefore, both soluble sugars and starch as energy sources decreased in the leaf inversion treatments at $20 \mathrm{~d}$ after leaf inversion.

Photosynthesis is a complex physiological process in which sunlight is converted into chemical energy in carbohydrates. $\mathrm{Chl}$ is an essential molecule in this process because it is the central pigment in photosynthesis. If its content is lowered, less solar energy is harvested, resulting in a decreased photosynthetic rate (Wen et al. 2011, Yan et al. 2015). In this study, when the abaxial surface was exposed to direct solar radiation, the $\mathrm{Chl} a, \mathrm{Chl} b$, total $\mathrm{Chl}$, and carotenoid contents of JY60 decreased $10 \mathrm{~d}$ after treatment, while there was no significant difference between the $\mathrm{Chl} a, \mathrm{Chl} b$, total $\mathrm{Chl}$, and carotenoid contents of the treatments in the XD27 cultivar. The Chl content was closely related to $P_{\mathrm{N}}$, which agrees with the results of Yao et al. (2017). The decreased $P_{\mathrm{N}}$ of JY60 in the main stem leaves treated with leaf inversion partly resulted from the decreased Chl content, which probably decreased the light energy conversion. Carotenoid content plays a vital role in protecting the photosynthetic apparatus from photooxidation damage (Demmig-Adams and Adams 1996). The decrease in carotenoid content in inverted leaves of JY60 aggravates the photooxidation damage of leaves under high light and high temperatures in summer.

The results of this study supported our hypothesis that the frequent occurrence of monsoon winds usually leads to inverted soybean leaves, which reduces gas exchange of leaves, and then reduces plant photosynthesis and nonstructural carbohydrates in soybean leaves. Further research may explore traits associated with mesophyll conductance to $\mathrm{CO}_{2}$ in leaf inversion treatments for both cultivars. A recent study showed that the application of potassium, green leaf volatiles, and straw mulch-based notillage could protect plants against damage from abiotic stress by activating antioxidant enzymes and osmolyte accumulation (Singh et al. 2015, Cao et al. 2019, Tian et al. 2019, Yang et al. 2020). This study provides a theoretical basis for exploring a possible methodology for alleviating the decrease in plant photosynthesis under leaf inversion.

Conclusions: The abaxial surface of fully expanded leaves exposed to direct solar radiation decreased the $P_{\mathrm{N}}$ and $P_{\text {Nmax }}$ by 25.8 and $32.0 \%$, respectively, at the seed-filling stage, which can be attributed mainly to the deactivation of PSII reaction center ( $\mathrm{RC} / \mathrm{CS})$. Leaf inversion leads to smaller stomata and thinner leaves, and the $\mathrm{T}_{\text {leaf }}$ increased by $7.6 \%$ at $10 \mathrm{~d}$ after leaf inversion, partly because of decreased $E$. The light-insensitive cultivar XD27 showed a higher capability to maintain $T_{\text {leaf }}$, WUE, AQY, soluble sugar, and chlorophyll under leaf inversion than the light-sensitive cultivar JY60. The AQY decreased in leaf inversion treatments, suggesting that leaf inversion decreased the potential photosynthetic capacity. Leaf inversion decreased the soluble sugar content of soybean leaves, suggesting that monsoon-induced leaf inversion reduced leaf photosynthesis, which might be attributed to decreased self-repairing capability after leaf inversion. This study provides a more comprehensive understanding of the effect of leaf inversion on leaf photosynthesis and the outputs of nonstructural carbohydrates. Future studies using green leaf volatiles, foliar potassium fertilizers, and straw mulching are required to explore a possible methodology for reducing the photosynthetic damage caused by monsoon-induced leaf inversion.

\section{References}

Aasamaa K., Aphalo P.J.: The acclimation of Tilia cordata stomatal opening in response to light, and stomatal anatomy to vegetational shade and its components. - Tree Physiol. 37: 209-219, 2017.

Adamski J.M., Peters J.A., Danieloski R., Bacarin M.A.: Excess iron-induced changes in the photosynthetic characteristics of sweet potato. - J. Plant Physiol. 168: 2056-2062, 2011. 
Avola G., Cavallaro V., Patanè C., Giggi E.: Gas exchange and photosynthetic water use efficiency in response to light, $\mathrm{CO}_{2}$ concentration and temperature in Vicia faba. - J. Plant Physiol. 165: 796-804, 2008.

Bahamonde H.A., Gil L., Fernández V.: Surface properties and permeability to calcium chloride of Fagus sylvatica and Quercus petraea leaves of different canopy heights. - Front. Plant Sci. 9: 494, 2018.

Cai Y.P., Wang L.W., Chen L. et al:: Mutagenesis of GmFT2a and GmFT5a mediated by CRISPR/Cas9 contributes for expanding the regional adaptability of soybean. - Plant Biotechnol. J. 18: 298-309, 2020.

Cao Y., Ding W.W., Zhang J.Z. et al.: Significant down-regulation of urea cycle generates clinically relevant proteomic signature in hepatocellular carcinoma patients with macrovascular invasion. - J. Proteome Res. 18: 2032-2044, 2019.

Chen B.B., Zhang G.Y., Li P.H. et al.: Multiple GmWRI1s are redundantly involved in seed filling and nodulation by regulating plastidic glycolysis, lipid biosynthesis and hormone signalling in soybean (Glycine max). - Plant Biotechnol. J. 18: 155-171, 2020

Chen B.Y., Wang C.H., Tian Y.K. et al.: Anatomical characteristics of young stems and mature leaves of dwarf pear. - Sci. Hortic.Amsterdam 186: 172-179, 2015.

Couée I., Sulmon C., Gouesbet G. et al:: Involvement of soluble sugars in reactive oxygen species balance and responses to oxidative stress in plants. - J. Exp. Bot. 57: 449-459, 2006.

Dalberto D.S., Martinazzo E.G., Bacarin M.A.: Chlorophyll $a$ fluorescence reveals adaptation strategies in drought stress in Ricinus communis. - Braz. J. Bot. 40: 861-870, 2017.

Das R., Bhagawati K., Boro A. et al.: Relative performance of plant cultivars under respective water deficit adaptation strategies: A case study. - Curr. World Environ. 10: 683-690, 2015.

Demmig-Adams B., Adams III W.W.: The role of xanthophyll cycle carotenoids in the protection of photosynthesis. - Trends Plant Sci. 1: 21-26, 1996.

Durand M., Brendel O., Buré C., Le Thiec D.: Changes in irradiance and vapour pressure deficit under drought induce distinct stomatal dynamics between glasshouse and field grown poplars. - New Phytol. 227: 392-406, 2020.

Düring $\mathrm{H}$.: Stomatal and mesophyll conductances control $\mathrm{CO}_{2}$ transfer to chloroplasts in leaves of grapevine (Vitis vinifera L.). - Vitis 42: 65-68, 2003.

Earles J.M., Buckley T.N., Brodersen C.R. et al.: Embracing 3D complexity in leaf carbon-water exchange. - Trends Plant Sci. 24: 15-24, 2019.

Earles J.M., Guillaume T., Roddy A.B. et al.: Beyond porosity: 3D leaf intercellular airspace traits that impact mesophyll conductance. - Plant Physiol. 178: 148-162, 2018.

Earles J.M., Théroux-Rancourt G., Gilbert M.E. et al.: Excess diffuse light absorption in upper mesophyll limits $\mathrm{CO}_{2}$ drawdown and depresses photosynthesis. - Plant Physiol. 174: 1082-1096, 2017.

Ellsworth P.V., Ellsworth P.Z., Koteyeva N., Cousins A.B.: Cell wall properties in Oryza sativa influence mesophyll $\mathrm{CO}_{2}$ conductance. - New Phytol. 219: 66-76, 2018.

Evans J.R.: Leaf anatomy enables more equal access to light and $\mathrm{CO}_{2}$ between chloroplasts. - New Phytol. 143: 93-104, 1999.

Fanourakis D., Bouranis D., Giday H. et al.: Improving stomatal functioning at elevated growth air humidity: a review. J. Plant Physiol. 207: 51-60, 2016.

Fanourakis D., Hyldgaard B., Giday H. et al.: Stomatal anatomy and closing ability is affected by supplementary light intensity in rose (Rosa hybrida L.). - Hortic. Sci. 46: 81-89, 2019.

Farquhar G.D., von Caemmerer S., Berry J.A.: Models of photosynthesis. - Plant Physiol. 125: 42-45, 2001.
Feng L., Raza M.A., Li Z. et al.: The influence of light intensity and leaf movement on photosynthesis characteristics and carbon balance of soybean. - Front. Plant Sci. 9: 1952, 2019.

Flexas J., Cano F.J., Carriquí M. et al:: $\mathrm{CO}_{2}$ diffusion inside photosynthetic organs. - In: Adams III W.W., Terashima I. (ed.): The Leaf: A Platform for Performing Photosynthesis. Pp. 163-208. Springer, Cham 2018.

Hao L.H., Guo L.L., Li R.Q. et al.: Responses of photosynthesis to high temperature stress associated with changes in leaf structure and biochemistry of blueberry (Vaccinium corymbosum L.). - Sci. Hortic.-Amsterdam 246: 251-264, 2019.

Harrison E.L., Arce Cubas L., Gray J.E., Hepworth C.: The influence of stomatal morphology and distribution on photosynthetic gas exchange. - Plant J. 101: 768-779, 2020.

Herrmann H.A., Schwartz J.-M., Johnson G.N.: From empirical to theoretical models of light response curves-linking photosynthetic and metabolic acclimation. - Photosynth. Res. 145: 5-14, 2020.

Ichiro T., Hiroki O., Takashi F., Riichi O.: Light environment within a leaf. II. Progress in the past one-third century. J. Plant Res. 129: 353-363, 2016.

Iqbal N., Hussain S., Raza M.A. et al.: Drought tolerance of soybean (Glycine max L. Merr.) by improved photosynthetic characteristics and an efficient antioxidant enzyme system under a split-root system. - Front. Physiol. 10: 786, 2019.

Isoda A., Mori M., Matsumoto S. et al.: High yielding performance of soybean in northern Xinjiang, China. - Plant Prod. Sci. 9: 401-407, 2006.

Keunen E., Peshev D., Vangronsveld J. et al.: Plant sugars are crucial players in the oxidative challenge during abiotic stress: extending the traditional concept. - Plant Cell Environ. 36: 1242-1255, 2013.

Kromdijk J., Głowacka K., Leonelli L. et al.: Improving photosynthesis and crop productivity by accelerating recovery from photoprotection. - Science 354: 857-861, 2016.

Lawson T., Vialet-Chabrand S.: Speedy stomata, photosynthesis and plant water use efficiency. - New Phytol. 221: 93-98, 2019.

Li L., Shi Z.Y., Li L. et al.: Overexpression of ACL1 (abaxially curled leaf 1) increased bulliform cells and induced abaxial curling of leaf blades in rice. - Mol. Plant 3: 807-817, 2010.

Li P.M., Fang P., Wang W.B. et al.: The higher resistance to chilling stress in adaxial side of Rumex $\mathrm{K}-1$ leaves is accompanied with higher photochemical and non-photochemical quenching. Photosynthetica 45: 496-502, 2007.

Li Q.L., Mao H.P., Zuo Z.Y. et al.: Effects of nitrogen and phosphorus on the microstructure and ultrastructure of tomato leaves (Solanum lycopersicum). - J. Plant Nutr. 40: 17731783, 2017.

Lichtenthaler H.K.: Chlorophylls and carotenoids: pigments of photosynthetic biomembranes. - Method. Enzymol. 148: 350-382, 1987.

Martin C.E., Hsu R., Lin T.C.: Comparative photosynthetic capacity of abaxial and adaxial leaf sides as related to exposure in two epiphytic ferns in a subtropical rainforest in Northeastern Taiwan. - Am. Fern J. 99: 145-154, 2009.

Matthews J.S.A., Vialet-Chabrand S., Lawson T.: Acclimation to fluctuating light impacts the rapidity of response and diurnal rhythm of stomatal conductance. - Plant Physiol. 176: 19391951, 2018.

Nazar R., Umar S., Khan N., Sareer O.: Salicylic acid supplementation improves photosynthesis and growth in mustard through changes in proline accumulation and ethylene formation under drought stress. - S. Afr. J. Bot. 98: 84-94, 2015.

Pan J.Q., Guo B.L.: Effects of light intensity on the growth, 
photosynthetic characteristics, and flavonoid content of Epimedium pseudowushanense BL Guo. - Molecules 21: $1475,2016$.

Pandey R., Chacko P.M., Choudhary M. et al.: Higher than optimum temperature under $\mathrm{CO}_{2}$ enrichment influences stomata anatomical characters in rose (Rosa hybrida). - Sci. Hortic.-Amsterdam 113: 74-81, 2007.

Paradiso R., de Visser P.H.B., Arena C., Marcelis L.F.M.: Light response of photosynthesis and stomatal conductance of rose leaves in the canopy profile: the effect of lighting on the adaxial and the abaxial sides. - Funct. Plant Biol. 47: 639-650, 2020.

Paradiso R., Marcelis L.F.M.: The effect of irradiating adaxial or abaxial side on photosynthesis of rose leaves. - Acta Hortic. 956: 157-163, 2012.

Pires M.V., Almeida A.-A.F., Figueiredo A.L. et al.: Photosynthetic characteristics of ornamental passion flowers grown under different light intensities. - Photosynthetica 49: 593602, 2011.

Proietti P., Palliotti A.: Contribution of the adaxial and abaxial surfaces of olive leaves to photosynthesis. - Photosynthetica 33: 63-69, 1997.

Richardson F., Brodribb T.J., Jordan G.J.: Amphistomatic leaf surfaces independently regulate gas exchange in response to variations in evaporative demand. - Tree Physiol. 37: 869878, 2017.

Ruiz-Vera U.M., Siebers M., Gray S.B. et al.: Global warming can negate the expected $\mathrm{CO}_{2}$ stimulation in photosynthesis and productivity for soybean grown in the midwestern United States. - Plant Physiol. 162: 410-423, 2013.

Sefton C.A., Montagu K., Atwell B.J., Conroy J.P.: Anatomical variation in juvenile eucalypt leaves accounts for differences in specific leaf area and $\mathrm{CO}_{2}$ assimilation rates. - Aust. J. Bot. 50: 301-310, 2002.

Singh M., Kumar J., Singh S. et al.: Roles of osmoprotectants in improving salinity and drought tolerance in plants: a review. Rev. Environ. Sci. Biotechnol. 14: 407-426, 2015.

Soares-Cordeiro A.S., Driscoll S.P., Arrabaça M.C., Foyer C.H.: Dorsoventral variations in dark chilling effects on photosynthesis and stomatal function in Paspalum dilatatum leaves. J. Exp. Bot. 62: 687-699, 2011.

Tamagno S., Sadras V.O., Ortez O.A., Ciampitti I.A.: Allometric analysis reveals enhanced reproductive allocation in historical set of soybean varieties. - Field Crop. Res. 248: 107717, 2020.

Terashima I., Hanba Y.T., Tazoe Y. et al.: Irradiance and phenotype: comparative eco-development of sun and shade leaves in relation to photosynthetic $\mathrm{CO}_{2}$ diffusion. - J. Exp. Bot. 57: 343-354, 2006.

Terashima I., Hanba Y.T., Tholen D., Niinemets Ü.: Leaf functional anatomy in relation to photosynthesis. - Plant Physiol. 155: 108-116, 2011.

Thalmann M., Santelia D.: Starch as a determinant of plant fitness under abiotic stress. - New Phytol. 214: 943-951, 2017.

Tian S.F., Guo R.Z., Zou X.X. et al.: Priming with the green leaf volatile (Z)-3-hexeny-1-yl acetate enhances salinity stress tolerance in peanut (Arachis hypogaea L.) seedlings. - Front. Plant Sci. 10: 785, 2019.

Turner N.C., Singh D.P.: Responses of adaxial and abaxial stomata to light and water deficits in sunflower and sorghum. New Phytol. 96: 187-195, 1984.

Verboven P., Herremans E., Helfen L. et al.: Synchrotron X-ray computed laminography of the three-dimensional anatomy of tomato leaves. - Plant J. 81: 169-182, 2015.

Voelker S.L., Brooks J.R., Meinzer F.C. et al.: A dynamic leaf gas-exchange strategy is conserved in woody plants under changing ambient $\mathrm{CO}_{2}$ : evidence from carbon isotope discrimination in paleo and $\mathrm{CO}_{2}$ enrichment studies. - Glob. Change Biol. 22: 889-902, 2016.

Wang Y., Noguchi K., Terashima I.: Distinct light responses of the adaxial and abaxial stomata in intact leaves of Helianthus annuus L. - Plant Cell Environ. 31: 1307-1316, 2008.

Wang Y., Noguchi K., Terashima I.: Photosynthesis-dependent and -independent responses of stomata to blue, red and green monochromatic light: differences between the normally oriented and inverted leaves of sunflower. - Plant Cell Physiol. 52: 479-489, 2011.

Wang Z.T., Sun Z.Q., Lu S.: Optimal vegetation index for assessing leaf water potential using reflectance factors from the adaxial and abaxial surfaces. - Comput. Electron. Agr. 172: 105337, 2020.

Wen K.J., Liang C.J., Wang L.H. et al.: Combined effects of lanthanumion and acid rain on growth, photosynthesis and chloroplast ultrastructure in soybean seedlings. Chemosphere 84: 601-608, 2011.

Wu Y.S., Gong W.Z., Yang W.Y.: Shade inhibits leaf size by controlling cell proliferation and enlargement in soybean. Sci. Rep.-UK 7: 9259, 2017.

Xiong D.L., Douthe C., Flexas J.: Differential coordination of stomatal conductance, mesophyll conductance, and leaf hydraulic conductance in response to changing light across species. - Plant Cell Environ. 41: 436-450, 2018.

Xu W.Z., Deng X.P., Xu B.C: Effects of water stress and fertilization on leaf gas exchange and photosynthetic light-response curves of Bothriochloa ischaemum L. Photosynthetica 51: 603-612, 2013.

Yan Y.H., Wan Y., Liu W.G. et al.: Influence of seed treatment with uniconazole powder on soybean growth, photosynthesis, dry matter accumulation after flowering and yield in relay strip intercropping system. - Plant Prod. Sci. 18: 295-301, 2015.

Yang F., Feng L.Y., Liu Q.L. et al.: Effect of interactions between light intensity and red-to-far-red ratio on the photosynthesis of soybean leaves under shade condition. - Environ. Exp. Bot. 150: 79-87, 2018.

Yang H.K., Wu G., Mo P. et al.: The combined effects of maize straw mulch and no-tillage on grain yield and water and nitrogen use efficiency of dryland winter wheat (Triticum aestivum L.). - Soil Till. Res. 197: 104485, 2020.

Yang H.K., Zhang X.Y., Chen B.L. et al.: Integrated management strategies increase cottonseed, oil and protein production: the key role of carbohydrate metabolism. - Front. Plant Sci. 8: 48, 2017.

Yao X.D., Li C.H., Li S.Y. et al.: Effect of shade on leaf photosynthetic capacity, light-intercepting, electron transfer and energy distribution of soybeans. - Plant Growth Regul. 83: 409-416, 2017.

Yu H.Y., Murchie E.H., González-Carranza Z.H. et al.: Decreased photosynthesis in the erect panicle 3 (ep3) mutant of rice is associated with reduced stomatal conductance and attenuated guard cell development. - J. Exp. Bot. 66: 1543-1552, 2015.

Yusuf M.A., Kumar D., Rajwanshi R. et al.: Overexpression of $\gamma$-tocopherol methyl transferase gene in transgenic Brassica juncea plants alleviates abiotic stress: Physiological and chlorophyll $a$ fluorescence measurements. BBA-Bioenergetics 1797: 1428-1438, 2010.

Zhang Z.S., Li Y.T., Gao H.Y. et al.: Characterization of photosynthetic gas exchange in leaves under simulated adaxial and abaxial surfaces alternant irradiation. - Sci. Rep.-UK 6: 26963, 2016.

(C) The authors. This is an open access article distributed under the terms of the Creative Commons BY-NC-ND Licence. 